\title{
Nationalism, Patriotism, and Essentialism in the Construction of Brazilian National Identity
}

\author{
Eldo Lima Leite ${ }^{*}, 1$ \\ Orcid.org/0000-0002-5152-8353 \\ Andreza Silene Silva Ferreira ${ }^{1}$ \\ Orcid.org/0000-0001-9068-0262 \\ José Roniere Morais Batista ${ }^{2}$ \\ Orcid.org/0000-0002-9055-7544 \\ José Luiz Álvaro Estramiana ${ }^{3}$ \\ Orcid.org/0000-0002-3017-0305 \\ Ana Raquel Rosas Torres ${ }^{1}$ \\ Orcid.org/0000-0002-3161-0309 \\ ${ }^{1}$ Universidade Federal da Paraíba, João Pessoa, PB, Brasil \\ ${ }^{2}$ Universidade Federal de Campina Grande, Campina Grande, PB, Brasil \\ ${ }^{3}$ Universidade Complutense de Madrid, Madrid, Espanha
}

\begin{abstract}
The main aim of this study was to test the hypothesis that nationalism and patriotism are fundamental elements in the degree of identification with the Brazilian nation and that essentialism has a mediating role in the relationship between nationalism, patriotism and national identity. A total of 229 university students took part in this study, with a mean age of 20 years; $28 \%$ were men and $71.2 \%$ women. The results of this study show that Brazilian national identity is a multifaceted construct that can be explained by taking into account factors such as nationalism, patriotism, and essentialism. In relation to the role played by these variables in the model, our hypothesis that essentialism acts as a mediating variable in the relationship between patriotism, nationalism, and national identity was confirmed. Even though essentialism explains national identity, it does not have a constitutive role, because of its process-based nature. It explains perceived national identity in terms of homogeneous attributes. These results help us in understanding the role of nationalism, patriotism, and essentialism in the construction of the Brazilian national identity.
\end{abstract}

Keywords: National identity, Patriotism, Nationalism, Essentialism.

* Mailing address: Rua Comerciante Alfredo Ferreira da Rocha, $n^{\circ}$ 1745, Bairro Mangabeira, João Pessoa, PB, Brazil 58055-541. Phone: +55 83 99647-4692. E-mail: eldolima@gmail.com

This research was supported by funding from National Council for Scientific and Technological Development (CNPq). 


\section{Nacionalismo, Patriotismo e Essencialismo na Construção da Identidade Nacional Brasileira}

\section{Resumo}

Este trabalho objetivou testar a hipótese de que o nacionalismo e o patriotismo são elementos definidores do grau de identificação com a nação brasileira e que o essencialismo tem um papel mediador na relação entre o patriotismo, o nacionalismo e a identidade nacional. Participaram deste estudo 229 estudantes universitários com idades média de 20 anos, $D P=3,6$; sendo $28,8 \%$ do sexo masculino e $71,2 \%$ do sexo feminino. Os resultados demonstram que a identidade nacional brasileira é um construto multifacetado e que pode ser explicada a partir de fatores como patriotismo, nacionalismo e essencialismo. Referente ao papel destas variáveis no modelo, corroboramos nossa hipótese de que o essencialismo funciona como uma variável mediadora da relação entre patriotismo, nacionalismo e identidade nacional. Apesar do essencialismo explicar a identidade nacional, o seu papel não é constitutivo, mas processual. Seria o pensamento essencialista quem explicaria a parcela da identidade nacional percebida em termos de atributos homogêneos. Neste sentido, ele funciona como um viés cognitivo através do qual os indivíduos percebem e organizam, em termos categóricos, o seu grupo nacional. Estes resultados nos ajudam a entender o papel que o nacionalismo, o patriotismo e o essencialismo têm na construção da identidade nacional brasileira.

Palavras-chave: Identidade nacional, Patriotismo, Nacionalismo, Essencialismo.

\section{Nacionalismo, Patriotismo y Esencialismo en la Construcción de la Identidad Nacional Brasileña}

\section{Resumen}

Este trabajo tuvo como objetivo comprobar la hipótesis de que el nacionalismo y el patriotismo son elementos definidores del grado de identificación con la nación brasileña y que el esencialismo tiene un papel mediador en la relación entre nacionalismo, patriotismo e identidad nacional. Participaron en este estudio 229 estudiantes universitarios, con una edad media de 20 años, $D E=3$; de los cuales el $28 \%$ eran hombres y el $71,2 \%$ mujeres. Los resultados demuestran que la identidad nacional brasileña es un constructo multifacético que puede ser explicado a partir de factores como el nacionalismo, el patriotismo y el esencialismo. En relación al papel de estas variables en el modelo, corroboramos nuestra hipótesis de que el esencialismo actúa como una variable mediadora de la relación entre patriotismo, nacionalismo e identidad nacional. A pesar de que el esencialismo explica la identidad nacional, su papel no es carácter constitutivo sino procesual. El pensamiento esencialista explica la identidad nacional percibida en términos de atributos homogéneos. En este sentido, actúa como un sesgo cognitivo a través del cual los individuos perciben y organizan, en términos categóricos, su grupo nacional. Estos resultados nos ayudan a entender el papel que el nacionalismo, el patriotismo y el esencialismo juegan en la construcción de la identidad nacional brasileña.

Palabras clave: Identidad nacional, Patriotismo, Nacionalismo, Esencialismo.

The study of Brazilian national identity has been considered a topic of growing interest, due to the greater relevance of Brazil in the world economic scenario (Cavusgil \& Kardes, 2013). It is considered a social challenge (Sobral \&
Vala, 2010; Terlouw, 2013), one of the most politically significant phenomena of our time (Anderson, 1991).

However, social psychologists have conferred little importance on the question of why 
individuals feel, identify, struggle, and die for their countries (Reicher \& Hopkins, 2001). In the social psychology area, few articles have been published about Brazilian national identity (Lima, Torres, \& Techio, 2016). In a survey carried out on the CAPES Periodicals Portal using the keywords "brazilian national identity", selecting articles published in Portuguese, Spanish, and English between the years 2007 and 2017, 81 results were found, of which only 6 were related to Brazilian national identity, with none being published in the social psychology area.

The concept of national identity involves, in some way, the sense of political community (Garcia, 2015; Smith, 1991), adherence to an imagined community (Anderson, 1991) to which individuals feel they belong (Barrett \& Davis, 2008; Lödén, 2014). In this study, we will address this sense of belonging to the community, to the national group, and will discuss how this identity is related to patriotic, nationalist, and essentialist beliefs.

National identities became evident after the Industrial Revolution (García-García, 1994), which allowed the precise delimitation of territories (Sahlins, 1989) and mass communication between individuals (Gellner, 1996). Another factor associated with the emergence of this identity would be intergroup conflicts, since they can be considered a factor of social cohesion, which contributes to constructing a sense of national identity (Colley, 1992). Thus, national identity arises in a context of new geographical boundaries (Nagle, 2013), when the individuals of one nation come into contact with other nations, which would legitimize and give meaning to the national identity itself (García-García, 1994).

Underlying the formation of national identity would be nationalism (Greenfeld \& Chirot, 1994; Hobsbawm, 2011; Leite, 2002), which would function as the ideological basis in the formation of national identity (Tinsley, 2014; Tse, 2014). Its main function would be to ensure that the inhabitants of a nation perceive themselves as a special people (Hastings, 1999). Nationalism is an ideology of modernity (Anderson, 1991; Billig, 1995; Gellner, 1996; Hobsbawm,
2011; Shulman, 2014; Smith, 2009), difficult to define (Kunhavalik, 2009). Nevertheless, beyond a social movement, nationalism can be considered as an ideological movement directed at the autonomy, unity, and identity of a population, considered as a real or potential nation (Smith, 1991).

Unlike nationalism, patriotism refers to a sense of loyalty tied to the nation (Sewpaul, 2009), and is often regarded as synonymous with nationalism (Billig, 1995; Sewpaul, 2009). However, patriotism is founded on the development of a sense of self-preservation, a morality of duty, and may even involve self-sacrifice (Acton, 1985). Patriotism is linked to love of country, but it is not synonymous with nationalism. While the latter refers to the belief in a cultural and/or ethnic unity, patriotism is linked to love, to the way of life that guarantees freedom and the common good of the nation (Viroli, 1997). In this study, we begin from the idea that patriotism and nationalism would be distinct phenomena, however, they would be related. While patriotism would be characterized by love and loyalty for the nation and by the pride of feeling part of a national community, nationalism would be characterized as an ideology on which the cultural construction of the nation, and consequently, of a differentiated territory and State, is based. This belief can, in addition, be associated with the idea of superiority of one nation over others (Kosterman \& Feshbach, 1989).

However, nationalism and patriotism would not be the only elements associated with the collective representation of a nationality. The individuals of a nation also refer to their collective reality on the basis of essentialist terms (PérezAgote, 1993). In fact, the first studies on national character alluded to a personality structure that would shape the collective identity of individuals (Leite, 2002), starting, therefore, from the belief in the existence of a collective soul. Essentialism refers to the belief that the members of a group share a personality structure that differentiates them from other groups, leading to a categorical thinking in social relations (Medin, Goldstone, \& Gentner, 1993; Yzerbyt, Rocher, $\&$ Schadron, 1997). Essentialism can be defined 
as a process of social categorization characterized by the belief in the existence of immutable attributes concerning the entities to which the essentialist categorization applies (Pereira, Álvaro, Oliveira, \& Dantas, 2011). In this sense it is an essentialism of a psychological nature (Estrada, Oyarzún, \& Yzerbyt, 2007).

The process of essentialization can occur in two ways: naturalism and entitativity. Naturalist essentialism originates from the idea that the characteristics shared by a group are based on physical and biological laws (Estrada et al., 2007). While essentialism via entitativity refers to an evaluation of the groups in terms of similarity and closeness of their members, who would be seen as individuals sharing a common destiny (Pereira et al., 2011), being therefore more linked to the idea of "nation" than the former. It is worth noting, however, that both the first and the second would lead to the perception of similarities of the members of a particular group and to the generalization of individual characteristics to the whole group (Calquin \& Estrada, 2011; Estrada, Yzerbyt, \& Seron, 2004).

Based on the discussion so far, we ask how these phenomena combine to form the national identity. Can nationalism, patriotism, and essentialism be used as an explanatory proposal for Brazilian national identity?

\section{Proposed Integrating Model}

National identity, from the perspective of social psychology, can be approached on the basis of social identity theory. Social identity can be defined as the portion of individual self-concept that derives from the knowledge of belonging to a group, along with the value associated with that belonging and its emotional meaning (Tajfel, 1981). The processes underlying social identity would be social categorization and social comparison. Categorization is the cognitive process characterized by accentuating the apparent differences, both physical and social, whose main function would be to simplify the social environment. In this perspective, the social category becomes a social group. However, what gives meaning to a group is social comparison, defined as the process by which the individual seeks to differentiate positively from the other groups in order to achieve a positive image (Techio, Costa, Moreira, \& Hora, 2015; Torres \& Camino, 2013). It is social identity that provides psychological reality to the group and enables the members to be united in their collective perceptions and behaviors (Tajfel, 1981).

Identity seen in terms of national groups, which would be national identity, can be defined as the portion of the self-concept that derives from belonging to a nation, along with the value associated with that belonging and its emotional meaning. In fact, nation is an elementary definer of identity, since it is an indispensable cognitive and emotional category for explaining the social world (García-García, Dorado, Álvaro, \& Torres, 2016).

On the other hand, the attachments of individuals to sacred places, to patriotic icons, to the myths that make up the history of a nation can be considered as constitutive elements of both national identity (Mitra \& König, 2013; Rodríguez, 2013; Smith, 1991; Zuev \& Virchow, 2014) as well as love of country. Thus, both nationalism, as a feeling of belonging to a nation, and patriotism, as a feeling of loyalty characteristic only to those people who feel part of that nation, would be explanatory factors of national identity. We still have to discuss the role that essentialism would have in an explanatory model of national identity.

The first studies in social psychology regarding nationality considered the naturalization of nations based on studies about the national character (Leite, 2002). The study of national identity, from the ethnic point of view, presupposed a belief in exclusive elements constituting such an identity (Smith, 1991). This perspective was abandoned because it served to disseminate the stereotypes and prejudices that propelled the wars of nationalism (García-García et al., 2016).

Essentialist thinking plays a fundamental role in the abandonment of ethnic nationalism and the replacement by a historical-cultural nationalism based on the adoption of categorical reasoning in intergroup relations (Pereira et al., 2011; Yzerbyt et al., 1997). Essentialist beliefs 
stem from the idea that individuals who belong to a nation share common characteristics and similar attributes that originate from their group membership. In this way, essentialism could explain national identity by representing a process underlying its constitution. Essentialism would be a mediator, by containing the heuristic of categorization, because it would be the cognitive process that would influence the perception of the national identity. This mediation would be partial because it would explain the portion of the national identity that refers to the process of homogenization based on the set of characteristics attributed to the national group. Thus, we hypothesize that essentialist beliefs act as a cognitive process that partially mediate the relationship between patriotism, nationalism, and national identity (Figure 1).

So, we are proposing an explanatory model of national identity based on patriotic, nationalist, and essentialist beliefs. Specifically, we intend to test the idea that nationalism and patriotism are elements defining the degree of national identity and that essentialism plays a mediating role in the relationship between patriotism, nationalism, and national identity.

\section{Method}

\section{Participants}

A total of 229 students from a public university in the state of Paraíba participated, with a mean age of 20 years, $S D=3.6 ; 28.8 \%$ male and $71.2 \%$ female. As for socio-economic level, $12.2 \%$ self-classified as being from the lower class, $47.6 \%$ lower-middle class, $30.6 \%$ middle class, and $8.7 \%$ upper-middle class. Regarding participant place of birth, $94.3 \%$ were from the Northeast region and 3\% from the Southeast and South regions.

\section{Instruments}

The instrument was composed of two parts. The first part was composed of four scales, all in seven-point Likert format:

National Identity Scale: was operationalized based on Tajfel's (1981) studies on social identity, defined as the feeling of belonging to a particular group, plus the evaluation and emotional meaning of that belonging. The scale presented a one-factor solution $(\alpha=.87)$.

Patriotism Scale: taken from the scale by Kosterman and Feshback (1989), who operationalize patriotism in terms of national pride. The scale presented a one-factor solution $(\alpha=.78)$.

Nationalism Scale: operationalized from the study by Terhune (1964), who conceives of nationalism in terms of national aspirations, considered as a consequence of a national conscience. National aspirations are thus defined as shared orientations in which one's country is expected to gain or extend its power over others. The scale presented a one-factor solution $(\alpha=.75)$.

Essentialism Scale: taken from the study by Calquin and Estrada (2011) and operationalized in terms of beliefs that the members of a group share a deep structure, which differentiates them from the other groups, which would lead to categorical thinking in social relations. The scale presented a one-factor solution $(\alpha=.74)$.

The second part consisted of a sociodemographic questionnaire containing questions related to age, sex, socio-economic level, and place of birth.

\section{Data Collection Procedures}

Sampling was non-probabilistic, by convenience. Participants were approached in the classroom and asked to participate in the research. A rapport was done informing that this was a study about how society views the Brazilian people. A free and informed consent form was then given to the participants. After signing the form, participants began to answer the questionnaires.

\section{Data Analysis Procedure}

The data were analyzed using SPSS-20 and AMOS-18 software. Descriptive analyses, correlations, and regressions were run. The hypotheses underlying the parametric tests were tested using single and multivariate diagnostics of normality, multicollinearity, and the pres- 
ence of outliers. For the mediation calculations, the steps proposed by Baron and Kenny (1986) were followed, and the confidence interval calculation was used to verify the indirect effects of the mediators using the bootstrapping technique
(Preacher \& Hayes, 2008). In this study, our hypothesis is that national identity is predicted both by patriotism and by nationalism, and these relations are simultaneously mediated by essentialism (Figure 1).

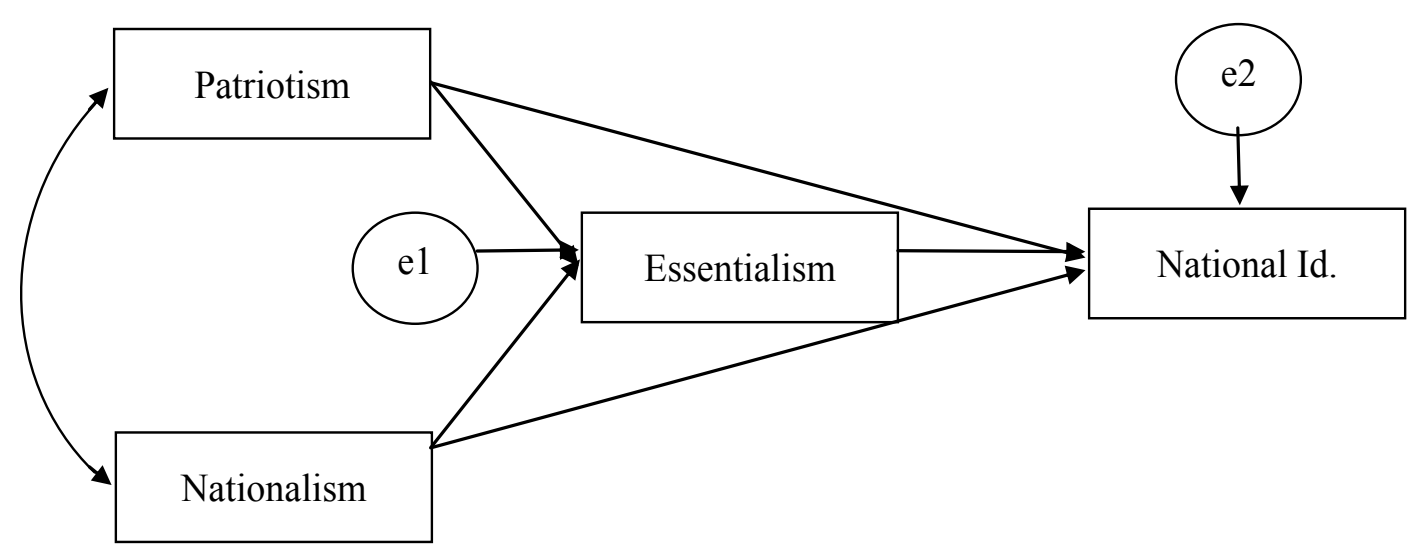

Figure 1. Mediation model of the relationship between Patriotism, Nationalism (IVs), Essentialism (Med), and National Identity (DV)

\section{Ethical Procedures}

After agreeing to participate in the study, participants signed a free and informed consent form, which clarified that the study was of a voluntary nature, that participant responses would be kept confidential in the publication of the data, and that they could leave the study at any time. The participants were also informed that, because it was an opinion poll, it would not entail any risk; and that the study would contribute to the area of social psychology and political psychology, on the topic of national identity, enabling a better understanding for Brazilians of one of the dimensions that constitutes their citizenship, national identity. All the recommendations and ethical cautions prescribed in Resolution 466/12 of the National Health Council, Protocol 034/15, were followed. CAAE [Certificate of Presentation for Ethical Consideration]: 41019015.4.0000.5188.

\section{Results}

Initially, a bivariate Pearson correlation analysis was done to verify how national identity, patriotism, nationalism, and essentialism are correlated. The results showed that these vari- ables present positive and significant relationships, indicating the possibility of establishing an explanatory model of national identity from them (Table 1).

Next, regression analyses (Table 2) using the Enter method were conducted to satisfy the conditions underlying the mediation analysis (Baron \& Kenny, 1986).

The results showed that both patriotism and nationalism significantly predict Brazilian national identity, satisfying condition 1 for the mediation hypothesis. Patriotism and nationalism significantly predict essentialism, satisfying condition 2. Essentialism presented a unique and significant effect on Brazilian national identity, satisfying condition 3 . Finally, we found that essentialism continues to predict Brazilian national identity, controlling the effects of patriotism and of nationalism, and that these variables have their effects reduced in the presence of the mediator variable, essentialism, satisfying condition 4 for a mediation to occur.

To verify if essentialism, in this model, acts as a mediator of the relationship between patriotism, nationalism, and Brazilian national identity, a regression analysis was run using AMOS-18 software. The existence of outliers 
Table 1

Analysis of Correlation between the Indicators of National Identity, Patriotism, Nationalism, and Essentialism

\begin{tabular}{lcccccc}
\hline & National Identity & Patriotism & Nationalism & Essentialism & \multicolumn{2}{c}{ Mean / SD } \\
\hline National Identity & 1 & - & - & - & 5.0 & 1.2 \\
Patriotism & $.652^{* *}$ & 1 & - & - & 5.0 & 1.0 \\
Nationalism & $.316^{* *}$ & $.240^{* *}$ & 1 & - & 4.8 & 1.0 \\
Essentialism & $.397^{* *}$ & $.414^{* *}$ & $.285^{* *}$ & 1 & 4.3 & 1.0 \\
\hline
\end{tabular}

$* * p<.01$

Table 2

Estimated Parameters for the Mediation Model

\begin{tabular}{|c|c|c|c|c|}
\hline \multicolumn{5}{|c|}{ Criterion Variables } \\
\hline & Step 1 & Step 2 & Step 3 & Step 4 \\
\hline & National Id. & Essentialism & National Id. & National Id. \\
\hline & $b$ & $b$ & $b$ & $b$ \\
\hline Intercept & .397 & $1.587 * * *$ & $2.969 * * *$ & .169 \\
\hline Patriotism & $.738 * * *$ & $.371 * * *$ & - & $.685^{* * *}$ \\
\hline Nationalism & $.193 * * *$ & $.189 * * *$ & - & $.166^{* *}$ \\
\hline \multirow[t]{5}{*}{ Essentialism } & - & - & $.472 * * *$ & $.143^{*}$ \\
\hline & $R=.673$ & $R=.456$ & $R=.397$ & $R=.681$ \\
\hline & $R^{2}$ adjusted $=.448$ & $R^{2}$ adjusted $=.201$ & $R^{2}$ adjusted $=.154$ & $R^{2}$ adjusted $=.457$ \\
\hline & $F(2,226)=93.41$ & $F(2,226)=29.63$ & $F(1,227)=42.36$ & $F(3,225)=64.92$ \\
\hline & $p<.001$ & $p<.001$ & $p<.001$ & $p<.001$ \\
\hline
\end{tabular}

${ }^{*} p<.05 ; * * p<.01 ; * * * p<.001$.

was evaluated using the squared Mahalanobis distance $\left(D^{2}\right)$ and the normality of the variables was evaluated using the univariate and multivariate coefficients of skewness $(S k)$ and kurtosis $(K u)$. No variable showed $S k$ and $K u$ values violating normal distribution $(S k<3$ and $K u<7-10$; Marôco, 2014). No observations showed $D^{2}$ values suggesting their removal as outliers. Multicollinearity was assessed using the VIF statistic. VIF values indicate that there is no multicollinearity among the model variables $\left(V I F_{S}<5\right)$. The indirect effects that indicate if the mediation hypothesis was satisfied were calculated using the bootstrapping technique with 5000 resamplings and confidence intervals at the $p<.05$ level.

The proposed model explained $46 \%$ of the variability of Brazilian national identity. It can be seen that all the trajectories are positive and statistically significant. So, first, we can see that 
patriotism had a significant relationship with nationalism. The patriotism variable had a total effect of .612 on Brazilian national identity, with a direct effect of .568 and an indirect effect, mediated by essentialism, of .044 . While the nationalism variable had a total effect of .170 on Brazilian national identity, with a direct effect of .146 and an indirect effect, mediated by essentialism, of .024. According to the bootstrapped resampling technique, the indirect effect $\left(c^{1}=\right.$
$.044)$ was significant at the $95 \%$ level with a CI ranging from .001 to $.047, p<.05$. The indirect effect $\left(\mathrm{c}^{2}=.024\right)$ was also significant at the $95 \%$ level with a CI ranging from .002 to $.030, p<.05$. Thus, we verified that the relationship between patriotism, nationalism, and Brazilian national identity was partially mediated by essentialism. Figure 2 presents the model with the standardized estimates of the regression coefficients and the $R^{2}$ of Brazilian national identity.

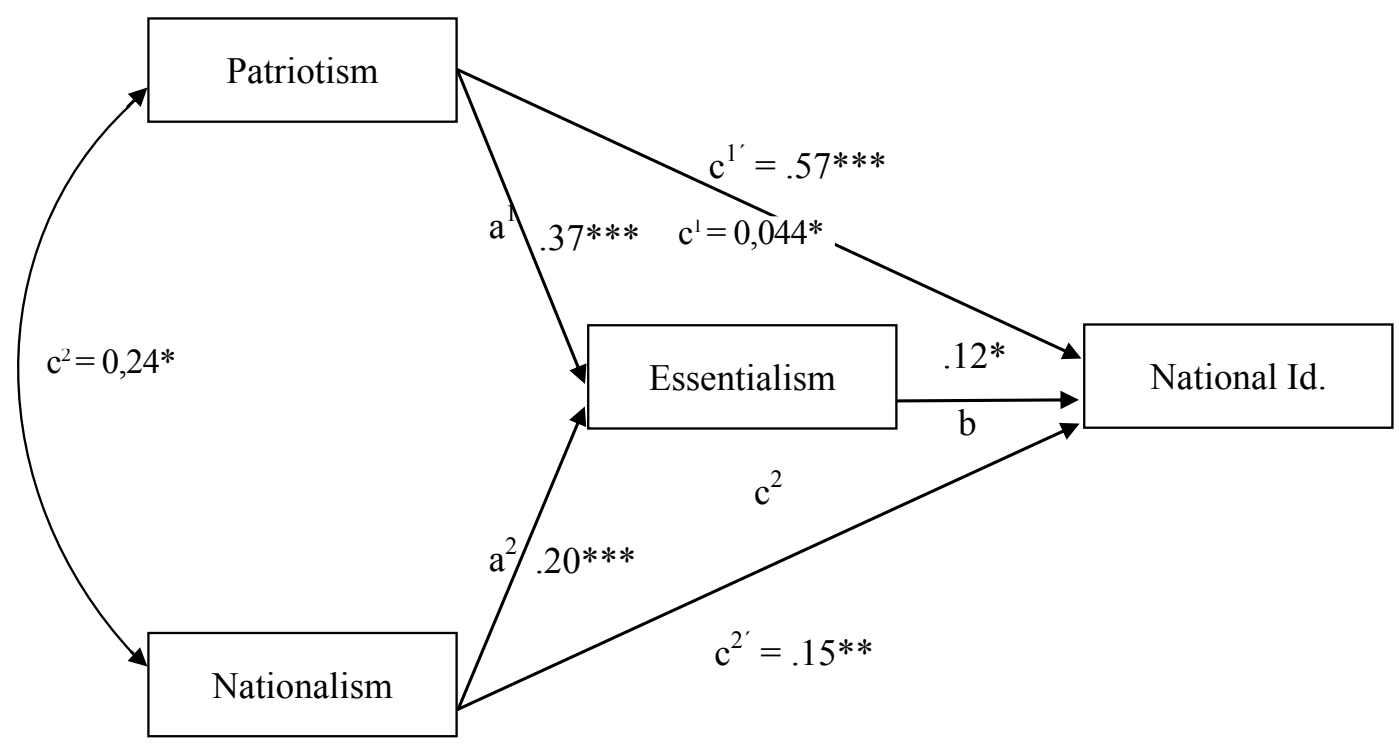

Figure 2. Mediation model of the relationship between Patriotism, Nationalism (IVs), Essentialism (Med) and National Identity (DV). $*_{p}<.05 ; * * p<.01 ; * * * p<.001$.

These results demonstrate, at first glance, that Brazilian national identity is a multifaceted construct and that it can be explained by the use of dimensions such as patriotism, nationalism, and essentialism. More specifically, Figure 2 demonstrates the specific roles of these variables in the regression model. Both patriotism and nationalism are constituent constructs of national identity. In this sense, the more individuals adhere to patriotic and nationalist beliefs, the greater the likelihood of presenting high levels of national identity.

Essentialism, on the other hand, played a distinct role, for it functioned as a kind of categorical belief that is activated by thinking in patriotic and nationalistic terms. Thus, when individuals think about their national identities, they do so in part based on essentialist beliefs, characterized in this study by the belief in the existence of a set of attributes inherent to Brazilians, as a group. This does not mean, however, that there is an essentialist constituent component of Brazilian national identity, but that social categorization, the underlying process of essentialist thinking, influences the way these individuals perceive their nationality.

\section{Discussion}

This study aimed to propose an explanatory model of national identity based on patriotic, nationalist, and essentialist beliefs. Specifically, we aimed to test the hypothesis that essentialism has a mediating role in the relationship between 
patriotism, nationalism, and national identity. The results corroborate our hypothesis, in the sense that essentialism partially mediated these relationships. This means that, even for individuals adhering to essentialist beliefs, patriotism and nationalism still continue to act as explanatory variables in the model.

In fact, both nationalism and patriotism are constructs that shape national identity (Greenfeld \& Chirot, 1994; Hobsbawm, 2011; Kosterman \& Feshbach, 1989; Lee, 2014; Piwoni, 2015; Tse, 2014). In this model it can be seen that both have a low correlation with one another (Ariely, 2012; Gries, Zhang, Crowson, \& Cai, 2011) and high predictive power for national identity (MillerIdriss \& Rothenberg, 2011; Pérez-Agote, 1993; Quiroga, 2014; Tartakovisky, 2011). indicating they are distinct phenomena (Kosterman \& Feshbach, 1989; Viroli, 1997).

With regard to essentialism, we consider in our model that this variable does not have a constitutive role in terms of nationality, but rather a processual one. This would be what would explain the portion of national identity perceived in terms of homogeneous attributes (Smith, 1991), inherent in the national group. This perception becomes meaningful in the process of comparison with other nations (Colley, 1992; Sahlins, 1989), which legitimizes and gives meaning to national identity (GarcíaGarcía, 1994). This would be in this way because underlying the essentialist thought would be the heuristic of social categorization (Pereira et al., 2011; Calquin \& Estrada, 2011; Estrada et al., 2007; Estrada et al., 2004; Pereira, Álvaro, \& Garrido, 2016), which simplifies reality by selecting a limited set of attributes to represent social groups, in this case the nation (Laxer, Carson, \& Korteweg, 2014). As the way individuals relate to social groups is similar to the way in which they relate to their own nation (Terhune, 1964; Troch, 2013), essentialism would also be working by simplifying the complexity of the "national identity" phenomenon, organizing it categorically (Patel, 2013, Raqib $\&$ Barreto, 2014). Since social categorization is a process common to essentialist thinking and national social identity, the constituent contents of essentialist beliefs associated with national groups would influence the way in which identity is perceived. In general, according to the proposed model, essentialism does not constitute national identity, but functions as a heuristic through which individuals organize information regarding national groups by means of the processes of simplifying the social environment, allowing a greater feeling of psychological control (Estrada et al., 2007; Estrada et al., 2004), and of social categorization, through which individuals anchor and give meaning to their experiences (Moscovici, 2015).

Because this is a new proposal explaining national identity, it is not yet possible to generalize these results to the entire population. The fact that the sample was composed of university students also represents a limitation of this study and points to other possibilities, with different participants, which make it possible to test this model in different contexts. The proposed model is not intended to encompass all the complexity of national identity (Sim \& Leith, 2014, Sperling, 2013, Storm, 2015; Zwet, 2015). Rather, its main objective is to understand how the variables, in this case patriotism, nationalism, and essentialism, are configured to explain this identity.

\section{Final Considerations}

Brazilian social psychology has conferred little importance on the study of national identity, even though it is one of the most politically significant phenomena of our time (Anderson, 1991). In an attempt to fill this empirical gap and take a step forward in the studies on national identity, we sought to present a new explanatory model of this identity, connecting variables from the cognitive and psychosocial sphere.

In thinking about national identity based on a model in which essentialism plays a processual role, we come to understand, to a certain extent, why theoreticians on national character have adopted an essentialist perspective (Leite, 2002; Mead, 1951) and why this has been associated 
with the formation of national stereotypes and prejudices (García-García et al., 2016). Thus, upon finding that the way essentialism explains national identity is different from traditional studies, we bring back once again the questions of how this identity is constituted and what other processes underlie this formation.

Since these results refer to a portion of the population, namely university students, and since the study design is correlational, it is not yet possible to make inferences for the Brazilian population as a whole. Studies with population samples representing the other regions of the country can give greater support to the proposed model, as well as add new perspectives regarding the construction of national identity (Leal, 2014), in order to clarify a bit more the phenomenon of national identity and be able to visualize its main social consequences.

\section{Authors' Contributions}

Substantial contribution in the concept and design of the study: Eldo Lima Leite; Ana Raquel Rosas Torres; José Luiz Álvaro Estramiana.

Contribution to data collection: José Roniere Morais Batista; Andreza Silene Silva Ferreira.

Contribution to data analysis and interpretation: Eldo Lima Leite; Andreza Silene Silva Ferreira; Ana Raquel Rosas Torres; José Luiz Álvaro Estramiana; José Roniere Morais Batista.

Contribution to manuscript preparation: Eldo Lima Leite; Andreza Silene Silva Ferreira; Ana Raquel Rosas Torres.

Contribution to critical revision, adding intelectual content: José Luiz Álvaro Estramiana; Ana Raquel Rosas Torres.

\section{Conflicts of interest}

The authors declare that they have no conflict of interest related to the publication of this manuscript.

\section{References}

Acton, J. E. E. D. (1985). Selected writings of Lord Acton. In J. Rufus Fears (Ed.), Essays in the history of liberty: Vol 1. Indianapolis, IN: Liberty Fund.
Anderson, B. (1991). Imagined Communities. Reflectinos on the Origen and spread of Nationalism. London: Verson.

Ariely, G. (2012). Globalisation and the decline of national identity? An exploration across sixty-three countries. Nations and Nationalism, 18(3), 461482. doi: 10.1111/j.1469-8129.2011.00532.x

Baron, R. M., \& Kenny, D. A. (1986). The moderator-mediator variable distinction in social psychological research: Conceptual, strategic, and statistical considerations. Journal of Personality and Social Psychology, 51(6), 1173-1182. doi: https://doi.org/10.1037//0022-3514.51.6.1173

Barrett, M., \& Davis, S. C. (2008). Applying social identity and self-categorization theories to children's racial, ethnic, national and state identifications and attitudes. In S. M. Quintana \& C. McKown (Eds.), Handbook of race, racism and the developing child (pp. 72-110). Hoboken, NJ: Wiley.

Billig, M. (1995). Banal Nationalism. London: Sage.

Calquin, D., \& Estrada, C. (2011). Esencialismo, su impacto en la percepción de similitud y el uso de diferente tipo de información en la formación de impresión. Psykhe, 20(1), 63-75. doi: http:// dx.doi.org/10.4067/S0718-22282011000100005

Cavusgil, S. T., \& Kardes, I. (2013). Brazil: Rapid development, internationalization, and middle class formation. Revista Eletrônica de Negócios Internacionais, 8(1), 1-16. doi: http://dx.doi. org/10.18568/1980-4865.811-16

Colley, L. (1992). Britons: Forging the Nation 17071837. London: Yale University Press.

Estrada, C., Oyarzún, M., \& Yzerbyt, V. (2007). Implicit Theories and Psychological Essentialism: Conceptual tools for the study of the relations between and within the groups. Psykhe, 16(1), 111121. doi: $10.4067 /$ S0718-22282007000100009

Estrada, C., Yzerbyt, V., \& Seron, E. (2004). Efecto del esencialismo psicológico sobre las teorías ingênuas de las diferencias grupales. Psicothema. 16(2), 181-186. Retrieved from http://www.redalyc.org/html/727/72716202/

García-García, J. (2015). Nación, sujeto y psique: la construcción psicológica del nacionalismo. Athenea Digital, 15(1), 333-346. doi: http:// dx.doi.org/10.5565/rev/athenea.1606

García-García, J. (1994). Nacion, identidad y paradoja: una perspectiva relacional del nacionalismo. 
Revista Internacional de Investigaciones Sociológicas, 64, 165-183. doi: 10.2307/40183739

García-García, J., Dorado, S. R., Álvaro, J. L., \& Torres, A. R. R. (2016). Nacionalismo e identidade nacional sob uma perspectiva psicossociológica. In M. E. O. Lima, A. R. R. Torres, \& E. M. Techio (Eds.), Identidade nacional e representações do Brasil: Abordagens integrativas (pp. 27-54). São Paulo, SP: Scortecci.

Gellner, E. (1996). O advento do nacionalismo e sua interpretação: Os mitos da nação e da classe. In G. Balakrishnan (Ed.), Um Mapa da Questão Nacional (pp. 107-154). Rio de Janeiro, RJ: Contraponto.

Greenfeld, L., \& Chirot, D. T. S. (1994). Natinalism and Agression. Theory and Society, 23(1), 79130. doi: https://doi.org/10.1007/BF00993674

Gries, P. H., Zhang, H. Q., Crowson, M., \& Cai, H. (2011). Patriotism, Nationalism and China's US Policy: Structures and consequences of Chinese National Identity. The China Quarterly, 205, 1-17. doi: 10.1017/S0305741010001360

Hastings, A. (1999). Special peoples. Nations and Nationalism. 5(3), 381-396. doi: 10.1111/j.13545078.1999.00381.x

Hobsbawm, E. J. (2011). Nações e Nacinalismo desde 1780: Programa, mito e realidade. (Special Issue, Vol. 18). Rio de Janeiro, RJ: Saraiva.

Kosterman, R., \& Feshbach, S. (1989). Toward a measure of patriotic and nationalistic atititudes. Poltical Psychology, 10(2), 257-274. doi: http:// dx.doi.org/10.2307/3791647

Kunhavalik, J. P. (2009). Os militares e o conceito de nacionalismo: Disputas retóricas na década de 1950 e início dos anos 1960. Santa Catarina, SC: Universidade Federal de Santa Catarina.

Laxer, E., Carson, R. D., \& Kortebeg, A. C. (2014). Articulating minority nationhood: Cultural and political dimensions in Québec's reasonable accommodation debate. Nations and Nationalism 20(1), 133-153. doi: 10.1111/nana.12046

Leal, J. (2014). What's (not) in a parade? Nationhood, ethnicity and regionalism in a diasporic context. Nations and Nationalism 20(2), 200-217. doi: 10.1111/nana.12062

Lee, J. W. (2014). Legacies of Japanese colonialism in the rhetorical constitution of South Korean national identity. National Identities, 16(1),
1-13. doi: http://dx.doi.org/10.1080/14608944.2 013.843516

Leite, D. M. (2002). O Caráter Nacional Brasileiro. São Paulo, SP: Livraria Pioneira.

Lima, M. E. O., Torres, A. R. R., \& Techio, E. M. (2016). Introdução. In M. E. O. Lima, A. R. R. Torres, \& E. M. Techio (Eds.), Identidade nacional e representações do Brasil: Abordagens integrativas (pp. 21-26). São Paulo, SP: Scortecci.

Lödén, H. (2014). Peace, love, depoliticisation and the domestic alien: National identity in the memorial messages collected after the terror attacks in Norway 22 July 2011. National Identities, 16(2), 157-176. doi: http://dx.doi.org/10.1080/1 4608944.2014 .918593

Marôco, J. (2014). Análise de Equações Estruturais: Fundamentos Teóricos, Softwares e Aplicações. Pêro Pinheiro, Portugal: Cafilesa.

Mead, M. (1951). The study of national character. In D. Lerner \& H. K. Lasswell (Eds.), The Policy Science (pp.70-85). Stanford, UK: Stanford University Press.

Medin, D., Goldstone, R., \& Gentner, D. (1993). Respects for similarity. Psychological Review, 100(2), 254-278. doi: http://dx.doi. org/10.1037/0033-295X.100.2.254

Miller-Idriss, C., \& Rothenbeg, B. (2011). Ambivalence, pride and shame: Conceptualisations of German nationhood. Nations and Nationalism 18(1), 132-135. doi: 10.1111/j.14698129.2011.00498.x

Mitra, S. K., \& König, L. (2013). Icon-ising national identity: France and India in comparative perspective. National Identities, 15(4), 357-377. doi: http://dx.doi.org/10.1080/14608944.2013.8 29430

Moscovici, S. (2015). Representações Sociais: Investigações em psicologia social. Petrópolis, RJ: Vozes.

Nagle, S. (2013). Confessional identity as national boundary in national historical narratives: Ireland and Germany compared. Studies in Ethnicity and Nationalism, 13(1), 38-56. doi: 10.1111/ sena. 12015

Patel, K. K. (2013). Where and when was Europe? Europeanness and its relationship to migration. National Identities, 15(1), 21-32. doi: http:// dx.doi.org/10.1080/14608944.2012.733152 
Pereira, M. E., Álvaro, J. L., \& Garrido, A. (2016). Essentialization processes in men 45 and women: A Brazil-Spain comparative study. Anales de Psicología, 32(1), 190-198.

Pereira, M. E., Álvaro, J. L., Oliveira, A. C., \& Dantas, G. S. (2011). Estereótipos e essencialização de brancos e negros: Um estudo comparativo. Psicologia \& Sociedade, 23(1), 144-153. Retrieved from http://www.scielo.br/pdf/psoc/ v23n1/a16v23n1

Pérez-Agote, A. (1993). Las Paradojas de La Nacion. Reis: Revista Española de Investigaciones Sociológicas, 61, 7-22. doi: 10.2307/40183615

Piwoni, E. (2015). Claiming the nation for the people: The dynamics of representation in German public discourse about immigrant integration. Nations and Nationalism, 21(1), 83-101. doi: 10.1111/nana.12084

Preacher, K. J., \& Hayes, A. F. (2008). Asymptotic and resampling strategies for assessing and comparing indirect effects in multiple mediator models. Behavior Research Methods, 40(3), 879891. doi: https://doi.org/10.3758/BRM.40.3.879

Quiroga, A. (2014). The three spheres. A theoretical model of mass nationalisation: The case of Spain. Nations and Nationalism, 20(4), 683700. doi: 10.1111/nana.12073

Raqib, M., \& Barreto, A. A. (2014). The Taliban, religious revival and innovation in Afghan nationalism. National Identities, 16(1), 15-30. doi: http://dx.doi.org/10.1080/14608944.2013.8435 17

Reicher, M., \& Ropkins, N. (2001). Self and nation. London: Sage.

Rodríguez, F. M. (2013). Representing the nation: Art and identity in Porfirian Mexico. National Identities, 15(4), 333-355. doi: http://dx.doi.org/ 10.1080/14608944.2013.811225

Sahlins, P. (1989). Boundaries. The Making of France and Spain in the Pyrenees. Berkeley, CA: University of California Press.

Sewpaul, V. (2009). On national identity, nationalism and Soccer 2010: Should social work be concerned? International Social Work, 52(2), 143-153.

Shulman, S. (2014). Nation versus class in Ukraine. Nations and Nationalism. 20(1), 154-171. doi: 10.1111/nana.12056
Sim, D., \& Leith, M. S. (2014). Scottish diasporic identities in the Netherlands. National Identities, 16(2), 139-155. doi: http://dx.doi.org/10.1080/1 4608944.2014.909799

Smith, A. D. (1991). National Identity. London: University of Nevada Press.

Smith, A. D. (2009). Ethno-symbolism and nationalism: A cultural approach. London: Routledge.

Sobral, J. M., \& Vala, J. (2010). Introdução. In J. M. Sobral \& J. Vala (Eds.), Identidade nacional, inclusão e exclusão social (pp. 17-29). Lisboa: Instituto de Ciências Sociais da Universidade de Lisboa.

Sperling, J. (2013). Belonging, beyond the nation: The significance and meaning of European identity for Latin American-origin youth in Spain. National Identities, 15(1), 67-84. doi: http:// dx.doi.org/10.1080/14608944.2012.733155

Storm, E. (2015). Nationalism studies between methodological nationalism and orientalism: An alternative approach illustrated with the case of El Greco in Toledo, Spain. Nations and Nationalism, 21(4), 786-804. doi: 10.1111/nana.12111

Tajfel, H. (1981). Human groups and social categories. Studies in social psychology. Cambridge, MA: Cambridge University Press.

Tartakovisky, E. (2011). National identity of highschool adolescents in an Era of Socio-Economic Change: Russia and Ukraine in the Post-Perestroika. Journal of Youth and Adolescence, 40(2), 231-244. doi: 10.1007/s10964-010-95096

Techio, E. M., Costa, P. N., Moreira, T. A., \& Hora, N. (2015). Identidade social baiana: Ser baiano na concepção de universitários. Revista Brasileira de Psicologia, 2(1), 79-89.

Terhune, K. W. (1964). Nationalism among foreign and American students: An exploratory study. The Journal of Conflict Resolution, 8(3), 256-270. doi: https://doi. org/10.1177/002200276400800304

Terlouw, K. (2013). Performing identities on a Dutch River Dike: National identity and diverging lifestyles. Studies in Ethnicity and Nationalism, 13(2), 233-255. doi: 10.1111/sena.12035

Tinsley, M. (2014). 'We Will Re-Member Them': Muslims in the Great War Semi-Centenary. Studies in Ethnicity and Nationalism, 14(3), 399-417. doi: 10.1111/sena.12101 
Torres, A. R. R., \& Camino, L. (2013). Grupos sociais, relações intergrupais e identidade social. In L. Camino, A. R. R. Torres, M. E. O. Lima, \& M. E. Pereira (Eds.), Psicologia Social: Temas e Teorias (pp. 515-539). Brasília, DF: Tecknopolitik.

Troch, P. (2013). Interactive nationhood: The relation between Croatian and Yugoslav national identity in the interwar period. Nations and Nationalism 19(4), 781-798. doi: 10.1111/nana.12045

Tse, T. K. (2014). Constructing Chinese identity in Post-colonial Hong Kong: A discursive analysis of the Official Nation-Building Project. Studies in Ethnicity and Nationalism, 14(1), 188-206. doi: 10.1111/sena.12073

Viroli, M. (1997). For Love of Country: An essay on patriostism and nationalism. Oxford, UK: Oxford University. doi: 10.1093/0198293585.001.0001

Yzerbyt, V., Rocher, S., \& Schadron, G. (1997). Stereotypes as explanations: A subjective essentialistic view of group perception. In R. Spears, P. J.
Oakes, N. Ellemers, \& S. A. Haslam (Eds.), The social psychology of stereotyping and group life (pp. 20-50). Malden, MA: Blackwell.

Zuev, D., \& Virchow, F. (2014). Performing nationalidentity: The many logics of producing national belongings in public rituals and events. Nations and Nationalism, 20(2), 191-199. doi: 10.1111/ nana.12063

Zwet, A. (2015). Operationalising national identity: The cases of the Scottish National Party and Frisian National Party. Nations and Nationalism, 21(1), 62-82. doi: 10.1111/nana.12091

(cc)BY (C) The Author(s), 2018. Open Access. This article is distributed under the terms of the Creative Commons Attribution 4.0 International License (http://creativecommons.org/licenses/by/4.0/), which permits unrestricted use, distribution, and reproduction in any medium, provided you give appropriate credit to the original author(s) and the source, provide a link to the Creative Commons license, and indicate if changes were made. 